\title{
An Exploration of EFL Teachers' Experience with Learning Disability Training
}

Exploración de la experiencia de los profesores de inglés como lengua extranjera con formación en dificultades de aprendizaje

Exploração da experiência dos professores de inglês como língua estrangeira com treinamento em dificuldades de aprendizagem

Jimalee SOWELL

https://orcid.org/o0oo-0003-3798-7235

Indiana University of Pennsylvania, Indiana, USA

hbqy@iup.edu

Larry SUGISAKI

https://orcid.org/0000-0002-9236-245X

Indiana University of Pennsylvania, Indiana, USA

jztv@iup.edu

Received: 26/09/2019

Accepted by peers: 03/02/2020
Sent to peer review: 07/01/2020

Approved: $18 / 02 / 2020$

DOI: 10.5294/laclil.2020.13.1.7

To reference this article (APA) / Para citar este artículo (APA) / Para citar este artigo (APA) Sowell, J., \& Sugisaki, L. (2020). An exploration of EFL teachers' experience with learning disability training. Latin American Journal of Content \& Language Integrated Learning, 13(1), 114-134. https://doi.org/10.5294/laclil.2020.13.1.7 
ABSTRACT. Approximately ten percent of learners have some sort of learning disability. This means that all English language instructors will encounter students with learning disabilities and could encounter students with learning disabilities in each class. Research has shown that different countries have varying degrees of infrastructure for identifying and accommodating learning disabilities. However, little research on the degree to which English language teachers in English as a Foreign Language (EFL) contexts have received training for learning disabilities has been carried out. This study had three goals: first, to identify whether the participants in the study, all of whom were EFL instructors, had received training for identifying and accommodating students with learning disabilities; second, among the teachers who had received training, to find out specifically the types of training they had received; and finally, to find out whether training had helped these teachers develop competence in assisting students with learning disabilities. The data were collected through a survey of past and current EFL teachers. Overall, the findings revealed that the majority of English language teachers surveyed had little to no training for accommodating learning disabilities, and the majority indicated that they did not feel confident assisting students with learning disabilities. Recommendations from this study include creating greater awareness for identifying and accommodating learning disabilities in EFL contexts among administrators and teachers as well as suggestions for EFL teachers to improve their knowledge of learning disabilities independently.

Keywords (Source: Unesco Thesaurus): EFL teachers; teacher; learning disabilities; learning disability training; learning disability identification; learning disability accommodation.

RESUMEN. Aproximadamente el diez por ciento de los estudiantes tienen algún tipo de dificultad de aprendizaje. Esto significa que todos los instructores de inglés encontrarán estudiantes con dificultades de aprendizaje y podrían encontrar estudiantes con dificultades de aprendizaje en cada clase. Los estudios demuestran que los diferentes países tienen diversos grados de infraestructura para identificar y adaptarse a las dificultades del aprendizaje. Sin embargo, son pocos los estudios realizados sobre el grado en que los profesores de inglés en contextos de inglés como lengua extranjera (EFL) han recibido entrenamiento sobre las dificultades de aprendizaje. Este estudio tenía tres objetivos: en primer lugar, identificar si los participantes del estudio, todos los cuales eran profesores de EFL, habían recibido entrenamiento para identificar y adaptarse a los estudiantes con dificultades de aprendizaje; en segundo lugar, entre los profesores que habían recibido entrenamiento, saber específicamente qué tipos de entrenamiento habían recibido; y, finalmente, saber si dicho entrenamiento les había ayudado a estos profesores a desarrollar la competencia para ayudar a los estudiantes con dificultades de aprendizaje. Los datos se recopilaron a través de una encuesta de maestros de inglés como lengua extranjera, pasados y actuales. En términos generales, los hallazgos revelaron que la mayoría de los profesores de inglés encuestados tenían poco o ningún entrenamiento para adaptarse a las dificultades de aprendizaje, y la mayoría indicó que no se sentían seguros al ayudar a los estudiantes con dificultades de aprendizaje. Entre las recomendaciones de este estudio están generar una mayor conciencia para identificar y adaptarse a las discapacidades de aprendizaje en contextos de EFL entre administradores y maestros, así como sugerencias para que los maestros de EFL mejoren su conocimiento de las dificultades de aprendizaje de forma independiente.

Palabras clave (Fuente: tesauro de la Unesco): docente; docente de inglés como lengua extranjera; ILE; inglés como lengua extranjera; dificultad en el aprendizaje; identificación de dificultad en el aprendizaje; adaptación de dificultad en el aprendizaje.

RESUMO. Cerca de dez por cento dos alunos têm algum tipo de dificuldade de aprendizagem. Isso significa que todos os professores de inglês encontrarão alunos com dificuldades de aprendizagem e podem encontrar alunos com dificuldades de aprendizagem em todas as aulas. Estudos mostram que os diferentes países têm diferentes graus de infraestrutura para identificar e se adaptar às dificuldades de aprendizagem. Porém, poucos estudos foram conduzidos sobre até que ponto os professores de inglês em contextos de inglês como língua estrangeira (EFL) receberam treinamento sobre as dificuldades de aprendizagem. Este estudo teve três objetivos: primeiro, identificar se os participantes do estudo, todos professores de inglês, receberam treinamento para identificar e se adaptar a alunos com dificuldades de aprendizagem; em segundo lugar, entre os professores que receberam treinamento, saber especificamente que tipos de treinamento receberam; e, finalmente, saber se esse treinamento ajudou esses professores a desenvolver a competência para auxiliar alunos com dificuldades de aprendizagem. Os dados foram coletados por meio de uma pesquisa com professores de inglês como língua estrangeira, antigos e atuais. Em termos gerais, os resultados revelaram que a maioria dos professores de inglês pesquisados tinha pouco ou nenhum treinamento em adaptação às dificuldades de aprendizagem, e muitos indicaram que não se sentiam seguros ajudando alunos com dificuldades de aprendizagem. Entre as recomendações deste estudo estão aumentar a conscientização para a identificação e adaptação às dificuldades de aprendizagem em contextos de EFL entre administradores e professores, bem como sugestões para professores de EFL para melhorar seus conhecimentos sobre dificuldades de aprendizagem de forma independente.

Palavras-chave (Fonte: tesauro da Unesco): professor; professor de inglês como língua estrangeira; ILE; inglês como língua estrangeira; dificuldade em aprender; identificação de dificuldades de aprendizagem; adaptação da dificuldade de aprendizagem. 


\section{Introduction}

It has been estimated that, in an average-size class of thirty students, ten percent of students have learning disabilities. This means that, inevitably, English language teachers will have students with learning disabilities and could have students with learning disabilities in each class (Butterworth \& Kovas, 2013). Some schools have adopted an inclusion model, which means that students with learning disabilities attend mainstream classes rather than a pull-out model that requires students diagnosed with learning disabilities to attend special classes. Research has shown that students with learning disabilities fare better in regular classes rather than special classes (Bulat et al., 2017; Fuchs \& Fuchs, 1994; Moore et al., 1998). This means that students with learning disabilities should be welcomed into mainstream classes and that teachers of mainstream English classes should be prepared to accommodate their needs. Whether students with learning disabilities are intentionally placed in a mainstream classroom or are in a mainstream classroom because they have not been diagnosed, English language teachers need to be able to identify and accommodate students with learning disabilities in their classrooms so that they can provide assistance. However, English language teachers may not have received any training on learning disabilities. As a result, English language teachers may not have any specific tools for identifying and accommodating students with learning disabilities. As a preliminary step towards working for increased training for English language teachers in assisting students with learning disabilities, the focus of this research inquiry was to learn about English as a Foreign Language (EFL) teachers' training. Specifically, the research was focused on finding out whether English language teachers in EFL contexts had received training regarding learning disabilities. For participants who had received training, the researchers sought to find out what kind of training they had received and whether they had found the training effective. The researchers also wanted to know what kind(s) of training EFL teachers would hope to have for improving their knowledge and ability to work with English language learners with learning disabilities.

For this research study, the researchers focused on teachers who taught English in EFL settings because they have both extensive experi- 
ence studying and teaching in EFL contexts. The researchers recognize that support systems for learning disabilities might be vastly different from country to country. The researchers in no way meant to imply that teachers in EFL contexts lack training that teachers in ESL contexts receive. In fact, they realize that English language teachers in EFL as well as ESL contexts might lack training in working with students with learning disabilities.

\section{Literature review}

\section{Defining learning disabilities}

The term learning disability was first defined by Samuel Kirk (1962) in his book, Educating Exceptional Children:

A retardation, disorder, or delayed development in one or more of the processes of speech, language, reading, writing, arithmetic, or other school subject resulting from a psychological handicap caused by a possible cerebral dysfunction and/or emotional or behavioral disturbances. It is not the result of mental retardation, sensory deprivation, or cultural and instructional factors. (p. 263)

Since Kirk's initial definition, there have been a number of countering definitions of learning disabilities, and a concrete definition agreed upon by a majority is still problematic; however, as a broad conceptual construct, learning disabilities can be understood as unexpected underachievement (Fletcher et al., 2007). Beyond the broad umbrella of underachievement, Burr et al. (2015) have specifically defined a learning disability as

a neurological condition that interferes with an individual's ability to store, process, or produce information. Learning disabilities can affect a student's ability to read, write, speak, spell, compute math, or reason as well as a student's attention, memory, coordination, social skills, and emotional maturity. (Burr et al., 2015, p. 3)

The National Center for Learning Disabilities (2014) stated that the most prevalent types of learning disabilities are the ones that target the areas of written expression (dysgraphia), math (dyscalculia), 
and reading (dyslexia). Other factors that could manifest as scholastic underperformance, such as lack of access to educational materials, should be eliminated. The Learning Disabilities Association of America stated that "Learning disabilities should not be confused with learning problems which are primarily the result of visual, hearing, or motor handicaps; of intellectual disability; of emotional disturbance; or of environmental, cultural, or economic disadvantages" (Learning Disability Association of America, 2018, para. 3).

\section{Some ways to determine learning disabilities}

In order to make an accurate diagnosis of a learning disability, a multiple-analysis that obtains data about an individual student by a team of specialists over a period of time needs to be carried out. This is not possible, however, in all contexts. In some cases, it is the responsibility of the individual teacher to observe students who might be at risk, record data, and interpret the data (Case \& Taylor, 2005). There are some methods that teachers might carry out on their own in determining the possible existence of a learning disability. First of all, the instructor needs to honestly evaluate the progression of the entire class carefully, considering whether instruction is culturally, pedagogically, and linguistically appropriate in meeting the needs of all learners. If most students are struggling with a given task or subject area, then the problem is usually with the instruction and not the students. If, on the other hand, most students are doing well, and only a few students are having problems, the instructor needs to closely evaluate the struggling students and offer additional help, if needed (Klingner, 2009). Unusual difficulty or struggle in the first language can also be a potential indicator of a learning disability according to Klingner and Eppollito (2014). They have noted some common shared behaviors in learning disabilities and L2 acquisition: difficulty following directions, possible poor auditory memory, difficulty concentrating, challenges in processing difficult language, and a tendency to become quickly frustrated. On the other hand, Klingner and Eppollito (2014) have also pointed out some important, though sometimes slight, differences in features of learning disabilities and difficulties learning a second language. While a student with learning disabilities might have difficulty with phono- 
logical awareness, a second-language learner might have difficulty distinguishing between sounds not in the L1. In addition, a student with learning disabilities might have difficulty in learning sound-symbol correspondence while an L2 student might have difficulty with sound-symbol correspondence when it differs from their L1, as well as difficulty pronouncing sounds that do not exist in the L1. Furthermore, while a student with a learning disability might have difficulty remembering sight words, a second language learner might struggle to remember sight words because they have not been acquired as part of the learner's lexicon (Klingner \& Eppollito, 2014).

\section{Training of learning disabilities}

Research on learning disability training for EFL instructors is largely absent from the literature. This lack of research is possibly an indicator that little training for identifying and accommodating learning disabilities has been carried out in EFL contexts. A pilot study by Lemperou et al. (2011) showed that EFL teachers in Greece had limited awareness of methods for identifying and assisting students with dyslexia in their classes, but that they had the desire to learn appropriate methods for helping those students. Smith (2006), who researched EFL teachers in the United Kingdom, found that the participants in the study lacked enough explicit instruction on disabilities. Due to this lack of training, many teachers in Smith's study admitted a lack of confidence in accommodating students with disabilities. Huang's (2011) study on developing pedagogy for students with learning disabilities in Taiwanese schools revealed the need to improve EFL training programs by including training on teaching language learners with learning disabilities.

\section{Method}

\section{Research site and data collection}

This research study was conducted at Indiana University of Pennsylvania (IUP) with a participant pool of current and former graduate students (masters and doctoral) from the English department. The partici- 
pants were currently enrolled or had previously been enrolled in one of the following programs at the time of the study: Ph.D. in Composition and Applied Linguistics, Ph.D. in Literature and Criticism, MA in Composition and Literature, MA in Literature, and MA in Teaching English as a Second Language (TESOL). The researchers focused on this particular population because of all the departments at IUP, students and alumni of the English department were among the most likely to have teaching experience in an EFL context.

To obtain the required data, the researchers created an online Qualtrics survey, which consisted of eight questions: three yes/ no questions, three short-answer questions, and two multiple-choice questions. After having their research study approved by the Indiana University of Pennsylvania Institutional Review Board (IRB), the researchers utilized the English department's listserv to distribute the survey to current students and alumni in the form of a participant recruitment announcement email, which included a link to the survey. However, the researchers did not have access to information regarding the number of students and alumni who currently receive IUP email, so they could not know how many potential study participants received the email. Potential participants could respond to the researchers' survey for a time frame of only one week (November 9-November 16, 2018). The researchers received 23 responses to their survey. The researchers did not collect any demographic data or identifying information other than the country or countries that participants currently teach in or had taught in previously.

\section{Data analysis}

The researchers collected both quantitative and qualitative data. Question one explained the study. Question two asked for participants' consent (Do you give your consent to take part in the survey?). Question three asked whether potential study participants had EFL teaching experience (Do you have English as a foreign language (EFL) teaching experience?). Participants who answered "no" to question three could not proceed with the survey. Question four asked which countries study participants had taught in or currently teach in (The survey did not ask participants to indicate a native or non-native English speaker 
status). Questions five through eight sought to find out about teachers' confidence in teaching students with learning disabilities, previous training they had undergone related to training for teaching students with learning disabilities, types of training they believed would be beneficial, and the types of learning disabilities they believed they had encountered in their English language classrooms.

Questions five and six were multiple-choice questions, and questions seven and eight asked for short answers. Questions five and six were analyzed using descriptive statistics. For questions seven and eight, the researchers engaged in exploratory coding. For the qualitative data, the researchers first conducted a "content analysis," which, according to Joffe and Yardley (2003), involves "establishing categories and then counting the number of instances in which they are used in a text or image" (p. 56). In other words, through content analysis, the researchers established frequency of commonly-occurring words. Once the researchers had established frequency, they determined emerging patterns, or codes. According to Saldaña (2016), "A code in qualitative inquiry is most often a word or short phrase that symbolically assigns a summative, salient, essence-capturing, and/or evocative attribute for a portion of language-based or visual data" (p. 4). Coding allowed the researchers to group and categorize the words or phrases. For this particular study, researcher one underwent an initial exploratory coding procedure to analyze the open-ended qualitative responses. After this initial coding process, in collaboration with researcher two, some codes were refined.

\section{Results}

\section{Countries study participants currently teach in or have taught in}

Through question four (Please indicate any countries you currently teach in or have previously taught in), the researchers wanted to find out which countries the participants had worked in. This question served to ensure that all participants had indeed worked in an (EFL) context 
where the official language of the country is not English. The country with the most respondents was China, with six participants, followed by Indonesia, with four, Saudi Arabia, with three, and South Korea, with two. The remaining countries each had one teacher participant.

Figure 1. Countries study participants currently teach in or have previously taught in

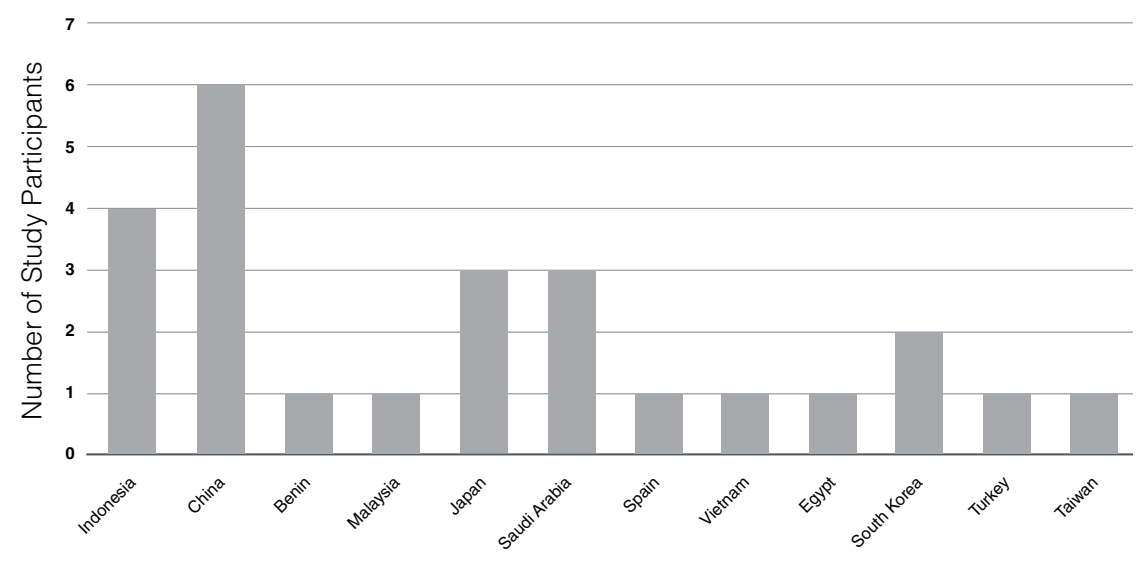

Countries Study Participants Currently Teach in or Previously Taught in

Source: Own elaboration.

\section{Study participants' confidence level for assisting students with learning disabilities}

With question five (Do you feel confident in your ability to assist students with learning disabilities in your classroom?), the researchers wanted to find out about the participants' level of confidence in assisting students with learning disabilities (Figure 2 shows the level of confidence that participants have in assisting students with learning disabilities in their classroom.) The majority of participants showed uncertainty in their ability to assist students with learning disabilities, with 13 participants (57 percent) responding "maybe." Six participants (26 percent) responded "no." Only four respondents (17 percent) of those surveyed indicated that they were confident in their ability to accommodate students with learning disabilities. 
Figure 2. FL teacher confidence-level for assisting students with learning disabilities

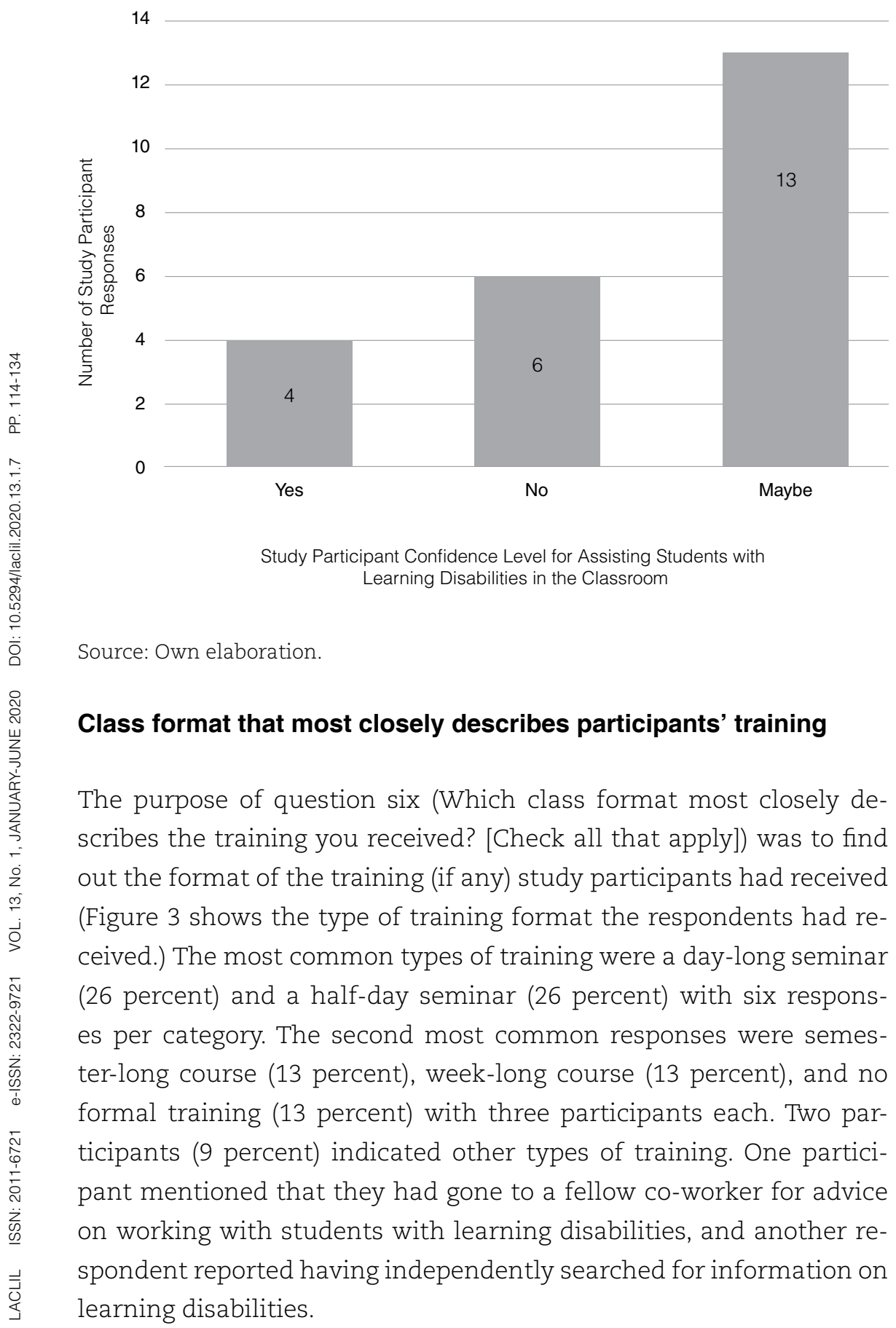


Figure 3. Type of class format that EFL teachers received for their learning disability training

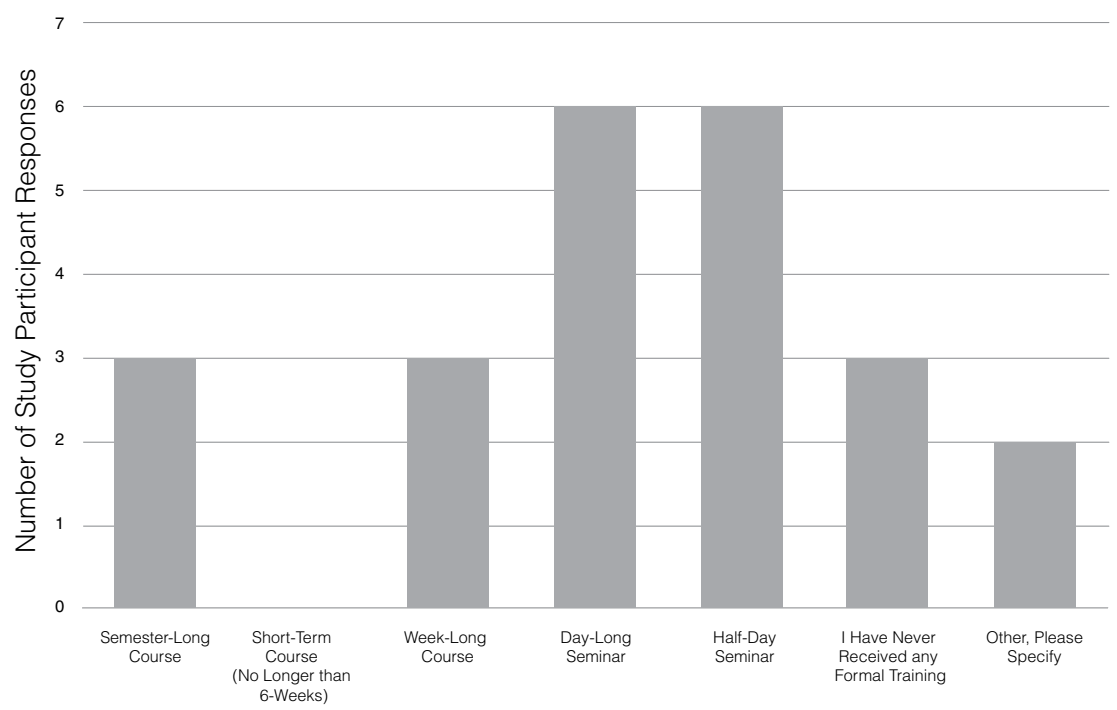

Type of Class Format that Study Participants

Recieved for their Learning Disability Training

Source: Own elaboration.

\section{Types of training participants indicated would be beneficial}

\section{Specific learning strategies}

With question seven (What type of training do you believe would be beneficial to you in terms of improving your understanding and performance in accommodating students with learning disabilities?), the researchers aimed to find out what kinds of learning disability training the respondents might find useful. According to participant responses, among the most preferred types of training was learning specific strategies. One survey participant felt it was important to know how to differentiate instruction for students with learning disabilities. Another survey participant suggested it was important to understand the common features of each learning disability, and one respondent asked what type of support or resources an instructor could offer when a student with a learning disability has difficulty completing an assignment or task. 


\section{Workshop}

A number of participants indicated that workshops could be beneficial because they could allow participants the opportunity to interact with an expert as well as the chance to problem-solve with colleagues. Additionally, participants indicated that hands-on training involving theoretical and practical information could be beneficial in learning how to accommodate students with learning disabilities.

\section{Online resources}

A less popular, but still relevant, preference was online resources. One respondent mentioned that online resources could be useful for both teacher and student. Another respondent indicated that a variety of online resources, such as journals, practical activities, and other materials on teaching strategies for accommodating students with learning disabilities could be useful.

Table 1. Types of training participants indicated would be beneficial

\begin{tabular}{|c|c|l|}
\hline Code & $\begin{array}{c}\text { Number of } \\
\text { Times Each } \\
\text { Code Appeared }\end{array}$ & \multicolumn{1}{c|}{ Examples } \\
\hline $\begin{array}{c}\text { Specific } \\
\text { Learning }\end{array}$ & 8 & $\begin{array}{l}\text { Knowing how to handle each different type of student } \\
\text { with a particular learning disability. } \\
\text { How am I supposed to adjust my teaching materials } \\
\text { according to different situations of disabled students? } \\
\text { We need to know the characteristics of each learning } \\
\text { disability and how to work around it as teachers. }\end{array}$ \\
\hline Workshop & 8 & $\begin{array}{l}\text { Incorporating yearly teacher training within our own } \\
\text { universities... } \\
\text { Allowed to ask questions among fellow teachers/ } \\
\text { teacher trainers about their own experiences. } \\
\text { Working with students with learning disabilities. } \\
\text { Being able to talk with an expert for Q\&A sessions. } \\
\text { Hands-on-training that provide both theoretical and } \\
\text { practical aspects to be implemented in making } \\
\text { instructional-related decisions. }\end{array}$ \\
\hline
\end{tabular}




\begin{tabular}{|c|c|l|}
\hline Code & $\begin{array}{c}\text { Number of } \\
\text { Times Each } \\
\text { Code Appeared }\end{array}$ & Examples \\
\hline $\begin{array}{c}\text { Online } \\
\text { Resources }\end{array}$ & 5 & $\begin{array}{l}\text { Learning about resources I can suggest to the } \\
\text { students... to receive help for their learning disability. } \\
\text { Resources online to help me accommodate this } \\
\text { population of student (journals, activities, materials on } \\
\text { helpful teaching approaches). }\end{array}$ \\
\hline
\end{tabular}

Source: Own elaboration.

\section{Types of learning disabilities participants have encountered in their classrooms}

\section{Can't specify/unsure}

The most frequently-occurring response regarding question 8 (What type of learning disabilities, if any, have you encountered in your classrooms?) was "unsure" or "can't specify." Some respondents indicated that they did not know the characteristics or symptoms of any of the common learning disabilities, so they had no frame of reference as to whether a student had a learning disability or not. Additionally, some EFL teachers responded that they did not have familiarity with learning disabilities and, therefore, did not want to make a guess at the kinds of learning disabilities their students might have for fear that they might misdiagnose a student with a learning disability when their struggles were the result of a cause other than a learning disability.

\section{Reading}

Several respondents indicated that they had worked with students who had displayed learning difficulties related to reading. One teacher mentioned that some of their students had particular difficulties determining the main point of a piece of writing and difficulties with retention. Another respondent reported having students who struggled to keep up with their peers because of reading comprehension difficulties.

\section{Short attention span/memory}

A few respondents mentioned short-term memory or short attention span as a possible sign of a learning disability. Some respondents indicated students' difficulty understanding a lecture as a potential sign 
of a learning disability. Other respondents understood difficulties in following instructions or comprehending lecture content as potential signs of learning disabilities. One teacher also mentioned the terms ADD and ADHD.

Table 2. Types of learning disabilities encountered in participants' classrooms

\begin{tabular}{|c|c|c|}
\hline Code & $\begin{array}{l}\text { Number } \\
\text { of Times } \\
\text { Each Code } \\
\text { Appeared }\end{array}$ & Examples \\
\hline $\begin{array}{l}\text { Can't } \\
\text { Specify/ } \\
\text { Unsure }\end{array}$ & 11 & $\begin{array}{l}\text { I could not tell you because I would not have known what } \\
\text { symptoms or characteristics to look for in someone with } \\
\text { learning disabilities. } \\
\text { This is a very tough question because I do not have a } \\
\text { background in learning disabilities and I feel I am only } \\
\text { making a guess. } \\
\text { I do not want to make a false accusation or just assume a } \\
\text { student who may just be struggling has a learning disability. }\end{array}$ \\
\hline Reading & 7 & $\begin{array}{l}\text { Students who have difficulty keeping up with the rest of } \\
\text { their classmates due to understanding the material they just } \\
\text { read. They have issues processing what they read. } \\
\text { Working with students with learning disabilities such as } \\
\text { dyslexia. }\end{array}$ \\
\hline $\begin{array}{c}\text { Short } \\
\text { Attention } \\
\text { Span/ } \\
\text { Memory }\end{array}$ & 5 & $\begin{array}{l}\text { ADD/ADHD } \\
\text { They struggled with my lecture style teaching approach. } \\
\text { Problems with their short-term memory. } \\
\text { I have also had students who have trouble understanding } \\
\text { instructions or my lectures on what I just explained. }\end{array}$ \\
\hline
\end{tabular}

Source: Own elaboration.

\section{Discussion}

\section{Lack of confidence in accommodating students with learning disabilities}

The first major takeaway from the results of our study revealed that the majority of participants were not confident in their ability to ac- 
commodate students with learning disabilities. The participants were either sure that they did not know how to accommodate learning disabilities or were noncommittal regarding their ability to help students with learning disabilities. Stainback and Stainback (1996) mentioned that there is a sort of "mystique" surrounding special education, with many teachers believing they are unfit to teach students with learning disabilities. Due to a lack of experience with this population, teachers might second guess their ability or look to pass off the responsibility of teaching students with learning disabilities to someone they perceive as better trained. In some cases, teachers who are not confident about assisting students with learning disabilities might give them preferential treatment. These teachers may feel as if they have to individually assist students with learning disabilities within a mainstream classroom. Wight (2015) pointed out that educators, EFL instructors included, don't always have the skills to design a course that is inclusive. However, many of the techniques teachers could use to accommodate students with learning disabilities benefit students without learning disabilities as well, such as differentiating instruction, diversifying course material, scaffolding lessons, and making the class interactive.

\section{Limited training for accommodating students with learning disabilities}

The results of the study not only revealed the low confidence level of EFL teachers, but also the limited extent of their learning disability training. The majority of participants reported that the learning disability teacher training they had received only lasted a day or less. While short trainings might be a good start, they are probably not robust enough to provide teachers with a complete toolkit for successfully working with students with learning disabilities. In a study on disability training with EFL instructors in the United Kingdom, Smith (2006) found that a longer training period proved to be more productive in helping teachers assist learners with physical and/or learning disabilities. In order to understand and competently apply accommodation strategies for assisting students with learning disabilities, teachers likely will need extensive and extended training. 


\section{Preferred types of training}

This study provided some information about the types of training that EFL teachers would prefer. Preferences were indicated through an open-ended question, so answers did not fit into neat categories and preferences exhibited some overlap. The most desired types of training indicated were specific learning strategies and workshops. Specific strategy training might be best carried out face-to-face, where participants can interact with an expert in the field and troubleshoot with colleagues. One of the key strengths of workshops is that they provide a platform for participants to share ideas and experiences (Sowell, 2016). Another desired type of training was for online resources-both for resources on ways instructors could help students with learning disabilities and resources that teachers could direct students with learning disabilities toward so that those students might independently find ways to help themselves. Some teachers might have indicated a preference for online resources because of the convenience of being able to access them at any time.

\section{Types of suspected disabilities}

A final outcome from the research study was that about half of the participants indicated that they were either unsure about or could not definitively identify the type of learning disabilities students presented with in their classrooms. One reason for this difficulty may be due to the fact that the characteristics or symptoms of learning disabilities vary from person-to-person. For example, when describing the difficulty of diagnosing dyslexia, Basu et al. (2014) described how:

There is no single pattern of difficulty that affects all people and not every symptoms of dysfunction is [sic] found in every child with dyslexia. Children with dyslexia show frequently a combination of one or of a variety of characteristics (Shaywitz, 2003). Difficulties related to reading, spelling, addition, verbal symptoms, and nonlinguistic difficulties can vary from individual to individual. (pp. 6-7)

Thus, a teacher could suspect that a student has a common learning disability such as dyslexia, but due to the differences in their symptoms and/or due to a lack of training, the teacher may second 
guess their assumption. An additional reason for participants' reluctance to identify learning disabilities in their classroom could be due to difficulties distinguishing between a learning disability and common second language acquisition issues. Identifying learning disabilities is complex but becomes even more challenging in the English language classroom. This difficulty can result from a number of factors. First of all, it can be very difficult to determine whether a student has a learning disability or a language learning difficulty because both learning disabilities and language acquisition difficulties often present with similar characteristics (Case \& Taylor, 2005; Chu \& Flores, 2011; Klingner, 2009; Klingner \& Eppollito, 2014). Often the errors made by students with learning disabilities and the errors committed by second-language learners overlap (Case \& Taylor, 2005; Cohan \& Honigsfeld, 2012; Klingner, 2014). Additionally, a student's struggles in the English language classroom are sometimes mis-identified as a learning disability when they are, in fact, the result of other causes (Abedi, 2006; Artiles \& Ortiz, 2002; Artiles et al., 2005; McCardle et al., 2005; Shore \& Sabatini, 2009). Some English language learners have been diagnosed with a learning disability when their scholastic underperformance is the result of not having had an adequate opportunity to develop language and literacy skills rather than the presence of a learning disability (Klingner \& Eppollito, 2014). Although there is an extensive amount of literature on learning disabilities and an extensive amount of literature on second-language acquisition, not much is known about learning disabilities amongst second-language learners (Klingner et al., 2006; Shore \& Sabatini, 2009).

\section{Recommendations for further research}

There is a clear need for further and more extensive research on learning disabilities training in EFL contexts in order to understand what types of training EFL teachers receive and the extent of the training received. Research is also needed to measure the efficacy of learning disabilities training on EFL teachers' practices to better understand what types of training might be most useful for EFL instructors. 


\section{Limitations of the study}

One limitation of this study was that it was carried out at one university in the United States and attracted a limited number of participants. Furthermore, the window to participate in the study only lasted for one week. In addition, this study did not inquire as to the type or length of general teacher training participants had engaged in. If participants had not undergone any sort of generalized teacher training, then it follows that it is unlikely that they would have participated in any sort of learning disability training. A further study on this same topic should seek to attract more participants and gain information about teachers' previous teacher training experiences in general.

\section{Conclusion}

The research from this study has shown that the participants in the study had received minimal or no training for identifying learning disabilities and methods for accommodating various learning disabilities in the English language classroom. Through this study, the researchers wanted to create an awareness of the lack of learning disability training for English language teachers and the need for such training. The researchers hope that institutions with EFL courses will become aware of the need for learning disability training, whether that means making existing learning disability training more robust or initiating learning disability training in institutions where it previously did not exist. Although it would be ideal for teachers to attend workshops with experts and to participate in ongoing training for learning disabilities, such arrangements might not be possible in every institution. Nonetheless, there are still ways that teachers can improve their knowledge of learning disabilities and accommodations. For instance, teachers can take online courses or access various online resources. Teachers might also share experience and knowledge amongst themselves and within their own institution or community. Since nearly all English language teachers will inevitably have students in their classes with 
learning disabilities, knowing how to accommodate them is important for creating a more inclusive classroom that is a productive learning space for all students.

\section{References}

Abedi, J. (2006). Psychometric issues in the ELL assessment and special education eligibility. Teachers College Record, 108(11), 2282-2303. https:// www.tcrecord.org/Content.asp?ContentId=12805

Artiles, A. J., \& Ortiz, A. A. (2002). English language learners with special education needs. Center for Applied Linguistics.

Artiles, A. J. Rueda, R., Salazar J., \& Higereda, I. (2005). Within group diversity and minority disproportionate representation: English language learners in urban school districts. Exceptional Children, 71(3), 283-300. https://doi.org/10.1177/001440290507100305

Basu, S. C., Poonam, D., \& Beniwal, A. (2014). A study to find the challenges faced by teachers in the class of child with dyslexia. Educationia Confab, 3(5), 1-8. https://www.academia.edu/34868113/A_Study_to_ Find_the_Challenges_Faced_By_Teachers_in_the_Class_of_Child_ with_Dyslexia

Berry, B., Daughtrey, A., \& Wieder, A. (2010). Preparing to lead an effective classroom: The role of teacher training and professional development programs. https://files.eric.ed.gov/fulltext/ED509718.pdf

Bulat, J., Hayes, A. M., Macon, W., Ticha, R., \& Abery, B. H. (2017). School and classroom disabilities inclusion guide for low-and middle-income countries. RTI Press. http://doi.org/10.3768/rtipress.2017.op.0031.1701

Burr, E., Hass, E., \& Ferriere, K. (2015). Identifying and supporting English learners with learning disabilities: Key issues in the literature and state practice. National Center for Education Evaluation and Regional Assistance. https://files.eric.ed.gov/fulltext/ED558163.pdf

Butterworth, B., \& Kovas, Y. (2013). Understanding neurocognitive developmental disorders can improve education for all. Science, 340(6130), 300-305. https://doi.org/10.1126/science.1231022

Case, R. E., \& Taylor, S. S. (2005). Language difference or learning disability? Answers from a linguistic perspective. The Clearing House: A Jour- 
nal of Strategies, Issues, and Ideas, 78(3), 127-131. https://eric.ed.gov $/ ? \mathrm{id}=\mathrm{EJ} 710918$

Chu, S. Y., \& Flores, S. (2011). Assessment of English language learners with learning disabilities. The Clearing House, 84(6), 42-48. https:// eric.ed.gov/?id=EJ950410

Cohan, A., \& Honigsfeld, A. (2012). Differentiating between learning disabilities and typical second language acquisition: A case study. Insights on Learning Disabilities 9(2), 13-20. https://works.bepress.com/ audrey-cohan/5/

Fletcher, J. M., Lyon, G. R., Fuchs, L.S., \& Barnes, M. A. (2007). Learning disabilities: From identification to intervention. Guildford Press.

Fuchs, D., \& Fuchs, L. S. (1994). Inclusive school movement and radicalization of special education reform. Exceptional Children, 60(4), 294-309. https://doi.org/10.1177/001440299406000402

Huang, Y. (2011). Developing English as a foreign language pedagogy for students with learning disabilities in Taiwan: Insights from individual cases (Publication No. 3488948) [Doctoral dissertation, University of Wisconsin-Madison]. ProQuest Dissertations and Theses.

Joffe, H., \& Yardley, L. (2003). Content and thematic analysis. In D. F. Marks \& L. Yardley (Eds.), Research methods for clinical and health psychology (pp. 56-68). Sage Publications Ltd.

Kirk, S. A. (1962). Educating exceptional children. Houghton Mifflin.

Klingner, J. K., Artiles, A. J., \& Mendez-Barletta, L. (2006). English language learners who struggle with reading: Language acquisition or LD? Journal of Learning Disabilities, 39(2), 108-128. https://doi.org/10.1177/ 00222194060390020101

Klingner, J. (2009). Learning disability versus learning English as a second language. Reading Today, 27(3), 15.

Klingner, J., \& Eppollito, A. (2014). English language learners: Differentiating between language acquisition and learning disabilities. Council for Exceptional Children.

Learning Disabilities Association of America. (2018). Types of learning disabilities. https://ldaamerica.org/types-of-learning-disabilities/

Lemperou, L., Chostelidou, D., \& Griva, E. (2011). Identifying the training needs of EFL teachers in teaching children with dyslexia. Procedia Social and Behavioral Sciences, 15(1), 410-416. https://doi.org/10.1016/j. sbspro.2011.03.113 
McCardle, P., Mele-McCarthy, J., Cutting, L., Leos, K., \& D’Emilio, T. (2005). Learning disabilities in English language learners: Identifying the issues. Learning Disabilities Research and Practice, 20(1), 1-5. https://doi. org/10.1111/j.1540-5826.2005.00114.x

Moore, C., Gilbreath, D., \& Maiuri, F. (1998). Educating students with disabilities in general education classrooms: A summary of the research. https:// files.eric.ed.gov/fulltext/ED419329.pdf

National Center for Learning Disabilities. (2014). The state of learning disabilities (3rd Ed.). National Center for Learning Disabilities. https:// www.ncld.org/wp-content/uploads/2014/11/2014-State-of-LD.pdf

Saldaña, J. (2016). The coding manual for qualitative researchers. SAGE.

Smith, A. M. (2006). Inclusion in English language teacher training and education (Unpublished doctoral dissertation). Lancaster University.

Shaywitz, S. (1998). Current concepts: Dyslexia. New England Journal of Medicine, 338(5), 307 - 312. https://doi.org/10.1056/NEJM199801293380507

Shore, J. R., \& Sabatini, J. (2009). English learners with reading disabilities: A review of the literature and the foundation for a research agenda. ETS Research Report Series, 2009(1), i-48. https://doi. org/10.1002/j.2333-8504.2009.tb02177.x

Sowell, J. (2016). How to conduct an ELT workshop. English Teaching Forum, 54(3), 2-9. https://files.eric.ed.gov/fulltext/EJ1114171.pdf

Stainback, W., \& Stainback, S. (1996). Inclusion: A guide for educators. Paul H. Brookes Publishing Company.

Wight, M. C. S. (2015). Students with learning disabilities in the foreign language learning environment and the practice of exemption. Foreign Language Annals, 48(1), 39-55. https://doi.org/10.1111/flan.12122 